\title{
O TRADUTOR, O TEXTO E O PROCESSO TRADUTÓRIO
}

\author{
Amanda Post da Silveira
}

A tradução não é domesticável em si, ela resiste a qualquer tentativa de sistematização em qualquer postura teórica ou histórica.

(Ottoni, 2005)

\begin{abstract}
RESUMO $^{\complement}$ : Este texto traz reflexões a respeito do processo de tradução com fundamentos da Análise de Discurso. O que se almeja é prover argumentos contra o efeito da ilusão de transparência da linguagem sustentado por teorias estruturalistas de tradução e defender que o sujeito tradutor é também um leitor especial que, através da tradução, se torna autor de um texto de materialidade diferente ao que lhe deu origem.
\end{abstract}

PALAVRAS-CHAVE: Tradução, Autoria, Análise de Discurso

\section{INTRODUÇÃO}

Ao pensar-se em tradução algo freqüente é ter-se a impressão que é possível encontrar correspondência fiel entre as línguas e é o que muitas teorias de tradução acreditam que exista. Porém, se considerar-se a opacidade da língua como algo que lhe constitui torna-se impossível acreditar em tal correspondência. Devido a isso é sugerido que o sujeito tradutor é também um leitor que produzirá outros sentidos no espaço interpretativo do processo tradutório.

As teorias de tradução tradicionais, estruturalistas, tendem a trabalhar com a dicotomia língua materna $x$ língua estrangeira como sendo "dois pólos antagônicos e opostos", em que o processo tradutório funcionaria como uma ponte atravessando os significados de uma língua para a outra (Ottoni, 2005:50). É interessante observar como essa tentativa de passagem é feita por aprendizes de L2 quando buscam encontrar um correspondente fiel entre as palavras de sua língua materna na língua outra. Ocorre um processo tal como se quisessem encontrar nas novas expressões um enunciado que lhes fosse universalmente compatível, mas em outra língua.

Isso acontece, segundo os pressupostos da Análise de Discurso (AD), quando o sujeito

(C) Trabalho desenvolvido no Grupo de Estudos Lingüísticos sob a orientação das professoras Dr. Amanda Eloina Scherer e Dr. Verli Petri da Silveira. tenta encontrar significados na língua outra e tem a ilusão, por efeito da ideologia - ilusão referencial - de que há transparência nesse processo (Orlandi, 2004). Mas, uma vez que discursivamente a língua é reconhecida pela sua opacidade, sendo também constituída pelo equívoco, uma tradução não pode ter "um" sentido, sendo possível apenas a produção de efeitos de literalidade, pois

A língua, enquanto um sistema sujeito a falhas, se inscreve na história para significar. $E$ são os efeitos dessa inscrição que encontramos na discursividade. (Orlandi, 2004: 149)

Considerando-se, também, que na língua intervém a sistematicidade e o imaginário, o sentido único não é possível devido aos diferentes sistemas inscritos em uma mesma língua e ao fato de que, para que o efeito de literalidade se concretizasse, seria necessário que o tradutor tivesse a mesma formação discursiva (FD) que o "outro", entendendo-se esta como o que determina o que pode e deve ser dito em circunstâncias de enunciação específicas (Orlandi, 2005). Além disso, seria necessário que a discursividade do sujeito tradutor tivesse passado pelo mesmo trabalho da história e do social do que a do outro, enfim, ele teria que ser o outro. Pelo fato de não ser viável, a compreensão imaginária que o tradutor tem da formação discursiva do outro produz no espaço interpretativo, possibilidades sujeitas à falha, ao equívoco, que, todavia o tornam autor de um texto de materialidade distinta do texto do outro, na medida que se identifica com a sua própria FD.

Além disso, deve-se levar em conta que os elementos lingüísticos que o texto oferece são apenas parte do que é necessário para que se possa fazer sentido na outra língua.

A inteligibilidade é um fato da língua. Desde que saibamos uma língua, o que é dito segundo sua ordem é inteligível. (...) Porém, para que seja interpretável é preciso que se domine as circunstâncias de enunciação aí incluído o co-texto. (Orlandi, 2004:149) 
Para tanto, o tradutor, que é um leitor que visa uma nova textualização, deve partilhar de saberes de pelo menos duas formações discursivas: a sua (língua alvo) e a do outro (de língua estrangeira). Essas relações são perceptíveis mesmo no fio discursivo. Nesse sentido, recortou-se os exemplos de Prade (2005):

$$
\begin{aligned}
& \text { “.. mate chimarrão com pinhão quente, } \\
& \text { (p. 7) } \\
& \text {... bitter mate with hot pine nuts, (p.7) } \\
& \text {.. bitterer mate mit heissen } \\
& \text { Ananastörtchen, (p. 13)" }
\end{aligned}
$$

Nos recortes das traduções analisadas por Prade (2005) da obra O tempo e o vento de Érico Veríssimo feitas para o inglês e para o alemão, tem-se que em língua inglesa, o tradutor associou a pinha do pinheiro araucária, que produz o pinhão, com a pinha do pinheiro pinus, que não produz semente comestível. Já na tradução para a língua alemã, possivelmente, feita a partir da obra traduzida para a língua inglesa, observa-se o tradutor associou pine à forma coloquial de pineapple e, portanto, "pinhão" foi traduzido como "torta de abacaxi".

Formulações como essas são passíveis de acontecer em tradução devido ao trabalho de compreensão do sujeito tradutor gerar uma interpretação sem historicização, o que sugere que a sua leitura na língua estrangeira não se aproxima da leitura do outro de língua estrangeira, dando ao texto nova materialidade e novos sentidos. A interpretação, então, seria o meio pelo qual são produzidos os sentidos pelo sujeito leitor e pelo outro de língua estrangeira entremeados de saberes outros, advindos de diferentes formações discursivas. Tal revela-se no trabalho do sujeito tradutor, aqui entendido como um leitor interpretante.

Diferentemente de reforçar a dicotomia língua materna $x$ língua estrangeira, pode-se dizer que, sob uma ótica desconstrutivista ${ }^{1}$, há uma (con)fusão necessária das línguas em processo tradutório, ou ainda, um "acontecimento que flagra a língua, está entre as línguas e faz parte das línguas. O tradutor é aquele que vai transformar e produzir significados, produzir outras impurezas na língua para a qual traduz." (OTTONI, 2005:51).
Então, pode-se dizer que as teorias estruturalistas de tradução sustentam-se sobre um efeito da linguagem, a ilusão de transparência, efeito ideológico entre sujeito e sentido que supõe que o sentido já está posto, determinado, o que pode sugerir ao sujeito tradutor a equivalência entre as línguas e, conseqüentemente, uma correspondência fidedigna entre um texto "original" e um texto traduzido. A língua é reconhecida por sua opacidade e pela forma como nela intervém a sistematicidade e o imaginário, aparecendo o equívoco como seu elemento constitutivo, Orlandi (2004), sendo assim, o produto da tradução será sempre uma releitura/reescritura/retextualização.

\section{CONCLUSÃO}

Quer-se argumentar, então, que não existe tradução que apresente uma correspondência completa com o texto que lhe deu origem, porque não há correspondência exata entre as línguas, assim como não há como o sujeito tradutor abster-se de sua própria formação discursiva e servir simplesmente de ponte para uma dicotomia língua de origem $\mathrm{x}$ língua alvo.

\section{REFERÊNCIAS BIBLIOGRÁFICAS:}

ORLANDI, E. P. Interpretação; autoria, leitura e efeitos do trabalho simbólico, $4^{\underline{a}}$ ed. Campinas: Pontes, 2004

ORLANDI, E. P. Análise de Discurso: princípios e procedimentos. 6a ed. Campinas: Pontes, 2005.

OTTONI, P. Tradução manifesta: double bind \& acontecimento, seguido de Fidelidade a mais de um: merecer herdar onde a genealogia falta, de Jaques Derrida/ Paulo Ottoni. Campinas: Editora da Unicamp; São Paulo: Edusp, 2005.

PRADE, H. G. A tradução de registros culturais em "O tempo e o Vento", palestra proferida na 3a Semana Acadêmica de Letras da UFSM Região e Regionalismo Gaúchos em outubro de 2005.

\footnotetext{
${ }^{1} \mathrm{Na}$ acepção de Derrida.
} 